\section{Dress for Success}

It is impossible to wear clothes without transmitting social signals. Every costume tells a story, often a very subtle one, about its wearer.

Desmond Morris in A Field Guide to Human Behavior M. Castillo, Editor-In-Chief

A couple of years ago, I visited the Mayo Clinic in Rochester, Minnesota, and was surprised to see that most physicians still wore suits, while here in Chapel Hill where I work, I am only one of a handful to do so. ${ }^{\star}$ I wear a suit because I feel that it makes for easy choices in the morning, looks respectful and elegant, and after a certain age (mine) it flatters the aging body. The "business suit" (sometimes also called a "lounge suit") appeared in the late 19th century, and typically all of its pieces ( 2 or 3 ) are made of the same cloth. Suits tend to compensate for physical variations by having no indication of a waistline and by adding padding to the shoulders; minor variations such as lapel width go in and out of style regularly. Business suits are a type of uniform, and today uniforms are worn mainly by 3 professions: the armed forces, commercial aviation, and medical staff. Smaller groups of individuals such as sports professionals and hygiene workers and even some students in private schools still wear uniforms. Commonly seen in medicine are 2 types of uniforms: white coats (or laboratory coats) and scrubs.

Most lab coats are knee length and have long sleeves to offer the most protection. Additionally, they are usually made of cotton because of its high capacity to absorb liquids. Professionals for whom sleeves prove uncomfortable or prone to contamination, such as microbiologists and pharmacists, prefer short-sleeve smocks. In a survey of nearly 300 doctors, only 1 in 8 wore a white coat, despite the fact that over $50 \%$ thought they should. ${ }^{1}$ Specialists who are the least likely to wear white coats include psychiatrists and pediatricians, while those more likely to do so are surgeons and gynecologists. Older physicians are also more likely to wear them than younger ones.

Scrubs were designed for surgical personnel but are now worn by nearly anyone who works in health care (they are also mandated in some prisons). Similar to lab coats, scrubs were initially white, but with the advent of modern operating room illumination, that color resulted in eye strain. During the 1950s and 1960s, most hospitals adopted green scrubs in an attempt to lessen this strain. Today scrubs vary in color, often distinguishing among different specialties, and those used by pediatricians may have cartoon characters printed on them. ${ }^{2}$ Because they are very comfortable, they are commonly used outside the hospital as pajamas, for working out, or just hanging out at home (it does upset me when I go to bar or restaurant and see hospital personnel in scrubs there). I also find it unfair to take the hospital germs home and then bring those from home to the hospital.

\footnotetext{
* The Mayo Clinic encourages their physicians to wear business suits rather than white coats because suits are thought to convey professionalism and expertise. ${ }^{20}$ http://dx.doi.org/10.3174/ajnr.A3942
}

Wearing a uniform, such as a white coat, alters the perception of those who see us and also affects the way the wearer thinks. In an experiment, students wearing white coats noticed twice as many errors during a test compared with those wearing street clothes. They also did better at spotting differences during tests designed to measure sustained attention. ${ }^{3}$ British patients prefer their male physicians in a suit and tie but their female physicians in white coats. ${ }^{4}$ In Great Britain, the favorite male attire seems to be a tweed sports jacket and a tie and informal shirt. Overall, 64\% percent of patients think that the way their physicians dress is very important, and $41 \%$ say they their confidence in their physicians' abilities is based on appearances. Casual dressing for doctors is a bad tactic: It decreases perceptions of authority regardless of sex, paradoxically decreases perceptions of friendliness and trust, and also lowers attractiveness. ${ }^{5}$ There are sex differences in perception, and female patients prefer their physicians in white coats, while male patients prefer them formally dressed. Thus, the best attire may be a white coat over formal wear and removal of the white coat when the occasion calls for it. The attitude toward physicians' dressing styles may be age-related. In a different study, $43 \%$ of teenagers responded that the way their physicians dressed made no difference and only $26 \%$ preferred them in white coats. ${ }^{6}$ Patients prefer their anesthesiologists to wear the traditional business suit and find blue jeans an undesirable choice. ${ }^{7}$

A different study, also involving anesthetists, found that patients had a preference for name tags, short hair, and white coats but disapproved of clogs, jeans, sneakers, and earrings. ${ }^{8}$ In a study done in Italy, patients also preferred formal dressing and name tags. ${ }^{9}$ This very complete study of patient preferences also rated the following as very highly favorable: short nails, well-kept teeth, and light makeup on females. The following received very low ratings: tattoos, piercings, obesity, sandals, long hair on men, and heavy makeup on women. In another large study done in South Carolina, all respondents preferred their physicians in white coats, followed by business and surgical (scrubs) attire, and last casually dressed (jeans and polo shirts). ${ }^{10}$ In the military where uniforms are standard, patients prefer their doctors in white coats over scrubs. ${ }^{11}$ In that same environment, nonwhites and Hispanics had higher rates of preference for more formal dress than other groups.

Not only do most patients show similar preferences but their parents do, too. A study performed at the Children's Hospital in Cincinnati showed that parents prefer and express more confidence in physicians who are formally dressed than in those without a white coat, no necktie, and tennis shoes. These preferences were independent of the severity of the illness, time of visit, insurance group, race, and sex. ${ }^{12}$ Some studies point out that white coats may not be completely innocuous to patients. The "white coat syndrome" is a phenomenon in which patients exhibit high blood pressure when facing someone dressed in a white lab coat. Female students at an American university were asked to rank the same teachers dressed in traditional business and Indian attire, 
and not surprisingly, the former received a more positive evaluation. ${ }^{13}$ Although females prefer their teachers formally dressed, mixed-sex college classes express positive ratings for instructors dressed in casual clothes (jeans, t-shirts, flannel shirts). ${ }^{14}$

When I was a resident in radiology, the dress code was always a lab coat, a necktie for men, and no scrubs or tennis shoes except when doing procedures. If we arrived at the hospital without a tie, the program director would take us to his office where he had a drawer full of ties from which we chose what to wear that day (I recall that most were ugly, perhaps an incentive not to forget them again). Neckties of different types have been worn since Roman times, but it was not until 1926 that the current necktie (the long one) was designed and became popular. Studies show that about $20 \%$ of neckties are contaminated by the third hour worn, often with antibiotic-resistant micro-organisms (the rate of contamination for lab coats is about $25 \%$, more if they contain polyester). ${ }^{15}$ Bow ties are also prone to contamination though less often than long ties and because both are seldom washed, colonization with micro-organisms may remain in them forever. Because of this, some companies have started to apply nanoparticles that presumably "lock" the silk fibers found in neckties, preventing bacteria from getting into them. In one study, these so-called "safety ties" were found to have more bacteria than regular ties! Counterintuitively, it was the knots of the ties and not their tips that contained more bacteria (perhaps because we tend to adjust them often). ${ }^{16}$ If one is going to wear a tie, it is better to wear a bow tie and change it every day. ${ }^{17}$

White coats also allow one to carry stuff in the pockets. In one study, 70 individuals were asked what their lab coat pockets contained. These were all clinicians, and regardless of their status, stethoscopes, pocket manuals, "to do" lists, and telephone numbers were the items most commonly found in their pockets. Faculty and older staff were not fond of carrying handouts from lectures that were popular among younger staff. Students and faculty both carried family pictures. When asked about the usefulness of these items, obviously medical equipment received higher scores, while lecture handouts were considered less useful than family photographs. $^{18}$

Wearing perfume or cologne at the hospital or clinic, whether you are the physician or the patient, is generally discouraged. A number of workplaces are adopting fragrance-free or scent-reducing policies. It is thought that strong smells may induce allergies or asthma and are frowned on by most hospital safety committees (taking this to an extreme, Harrison Medical Center in Bremerton, Washington, accepts only flowers that are "less" fragrant for their patients). In reality, most allergies are induced by specific proteins that fragrances do not contain because what gives them their odor is actually a series of volatile hydrocarbons, which are not known to stimulate the immune system but, in large concentrations, may result in chemical irritations. ${ }^{19}$ Anyway, because most soaps, shower gels, deodorants, and body lotions contain some fragrance nowadays, wearing perfume is less popular (reflected by the decreasing revenues of perfume/cologne sales in the last few years and the fact that most of today's perfumes and colognes are very mild).

For the time being, I will continue wearing a business suit on most days at work. I generally do not wear a white coat because I do not see patients, but as the evidence indicates, if you are consulting with patients it is a good idea to wear one and to change it often to keep it clean.

\section{REFERENCES}

1. BBC News. Doctors should wear white coats. http://news.bbc.co.uk/ 2/hi/health/3706783.stm. Accessed March 4, 2014

2. Wikipedia. Scrubs (clothing). http://en.wikipedia.org/wiki/Scrubs_ \%28clothing\%29. Accessed March 4, 2014

3. Adam H, Galinsky AD. Enclothed cognition. J Experimental Social Psychology 2012;48:918-25

4. McKinstry B, Wang JX. Putting on the style: what patients think of the way their doctor dresses. Br J Gen Pract 1991;41:275-78

5. Brase GL, Richmond J. The white-coat effect: physician attire and perceived authority, friendliness, and attractiveness. J Appl Soc Psychol 2004;34:2469-81

6. Neinstein LS, Stewart D, Gordon N. Effect of physician dress style on patient-physician relationship. J Adolesc Health Care 1985;6:456-59

7. Sanders LD, Gildersleve CD, Rees LT, et al. The impact of the appearance of the anesthetist on the patient's perception of the pre-operative visit. Anaesthesia 1991;46:1056-58

8. Hennessy N, Harrison DA, Aitkenhead AR. The effect of the anaesthetist's attire on patient attitudes: the influence of dress on patient perception of the anaesthetist's prestige. Anaesthesia 1993;48: 219-22

9. Sotgiu G, Nieddu P, Mameli L, et al. Evidence for preferences of Italian patients for physician attire. Patient Prefer Adherence 2012;6:36-67

10. Rehman SU, Nietert PJ, Cope DW, et al. What to wear today? Effect of doctor's attire on the trust and confidence of patients. Am J Medicine 2005;118:1279-86

11. Lund JD, Rohrer J, Goldfarb S. Patient attitudes toward the use of surgical scrubs in a military hospital clinic. Patient Prefer Adherence 2008;2:85-88

12. Gonzalez Del Rey JA, Paul RI. Preferences of parents for pediatric emergency physician's attire. Pediatr Emerg Care 1995;11:361-64

13. Chowdhary U. Instructor's attire as a biasing factor in students' ratings of an instructor. Clothing \& Textiles Research Journal 1988;6:17-22

14. Morris TL, Gorham J, Cohen SH, et al. Fashion in the classroom: effects of attire on student perceptions of instructors in college classes. Communication Education 1996;45:135-48

15. Abuannadi M. Should physicians be banned from wearing neckties in medical venues? General Surgery News 2011;38:4. http:// www.generalsurgerynews.com/ViewArticle.aspx?d $=\mathrm{In} \% 2 \mathrm{~B}$ the $\% 2$ BNews\&d_id=69\&i=April\%2B2011\&i_id=719\&a_id=16975. Accessed March 4, 2014

16. Bosch W, Hedges MS, Cawley JJ, et al. Do nano-treated neckties reduce the carriage of bacterial pathogens from neckties of physicians? In: Proceedings of the 48th Joint Annual Interscience Conference on Antimicrobial Agents and Chemotherapy and the 46th Infectious Diseases Society of America Annual Meeting, Washington, DC. October 25-28, 2008

17. Biljan MM, Hart CA, Sunderlad D, et al. Multicentre randomized double bind crossover trial on contamination of conventional ties and bow ties in routine obstetric and gynaecological practice. $B M J$ 1993;307:1582-84

18. Lynn LA, Bellini LM. Portable knowledge: a look inside white coat pockets. Ann Intern Med 1999;130:247-50

19. Senger E. Scent-free policies generally unjustified. CMAJ 2011;183: E315-16

20. Berry L, Bendapudi N. Working Knowledge for Business Leaders. Clueing in customers: why docs don't wear white coats or polo shirts at the Mayo Clinic. http://hbswk.hbs.edu/archive/3380.html. Accessed March 4, 2014 